\title{
«COMPASSIO»Y «CO-REDEMPTIO» EN LAS CANTIGAS DE SANTA MARÍA. CRUCIFIXIÓN Y JUICIO FINAL ${ }^{1}$
}

\author{
POR \\ ANA DOMÍNGUEZ RODRÍGUEZ \\ Universidad Complutense
}

The present study treats several miniatures of the «Códice Rico» of the Cantigas de Santa María (Escurial t.I.1.) that feature the Crucifixion and the Final Judgment in a way which was new for the Thirteenth century. Each exhibits the active participation of the Virgin in the Passion of Christ («Compassio») and in the Redemption of the human race («Co-Redemptio»).

La existencia de las versiones de la Crucifixión y Juicio Final que aparecen en el «códice rico» de las Cantigas de Santa María (Escorial, ms.T.I.1.) que fue señalada en un trabajo mío de 1981 quiso abrir una nueva ruta para la historiografía de las Cantigas de Santa María ${ }^{2}$. Pues al

\footnotetext{
${ }^{1}$ El texto corresponde a una conferencia (no publicada) sobre la «Compassio Mariae» $y$ «Virgo mediatrix» en las Cantigas de Santa María pronunciada en el Congreso Internacional de Estudios Medievales, celebrado en Leeds (Inglaterra) entre los días 15 y 16 de julio de 1997, en la sesión dedicada a las Cantigas de Santa María y coordinada por el profesor Stephen Parkinson de la Universidad de Oxford, bajo el título de «Cobras e som II». Este trabajo se relaciona, en parte, con mis investigaciones sobre los Libros de Horas y se ha beneficiado del proyecto PB95-0381 del DGICYT sobre «Libros de Horas en las Bibliotecas de España».

2 Vid «Iconografía evangélica en las Cantigas de Santa María» en «The International Symposium on the Cantigas...» New York, 19-21 Nov. 1981) en Studies on the Cantigas de Santa María. Art, Music and Poetry, por I. J. Katz y J. E. Keller (ed.), Madison, 1987, pp. 53-80. Anteriormente se publicó en Reales Sitios, 80, (1984) 37-44. Los estudios anteriores a mi trabajo se habían centrado en las, mucho más abundantes, cantigas de milagros, mientras que el mío llamaba la atención sobre las cantigas «de loor» o decenales, señalando las peculiaridades de su iconografía. Uno de los asistentes al Congreso me indicó que con mi trabajo abría una autopista para posteriores investigaciones. Vid. sobre las principales aportaciones a este congreso C. L. Scarborough, «A Summary of Research on the Miniatures of the CSM» en Bulletin of the Cantigueiros de Santa María, vol. I, n. 1 (1987) 41-49. También J. T. Snow, «An Overview of Recent Studies Devoted to the CSM» en el mismo boletín arriba citado, pp.5-10. Para los estudios anteriores sobre las CSM ver J. Snow, The Poetry of Alfonso X el Sabio. A Critical Bibliography, London, 1977. Entre 1982 y 1987 se publicó con periodicidad anual un Noticiero Alfonsí de A. J. Cárdenas de la Wichita State University que recoge las publicaciones sobre Alfonso X y su obra. Estudios más recientes sobre la obra de Alfonso se recopilan en A. J. Cárdenas, J. R. Craddock y B. de Marco, «A Decade of Alfonsine Studies: Working Notes and Bibliography» en Romance Philology, XLIX, 2 (1995) 193-244. Véase también M. V. Chico Picaza, «Cronología de la miniatura alfonsí. Estado de la cuestión», en Anales de Historia del Arte, 4 (1994) 569-576 («Homenaje al profesor Dr. D. José María de Azcárate»).
} 
estudiar como conjunto estas imágenes, que propuse llamar evangélicas, en las cantigas de loor, rompía con una larga tradición de los historiadores del arte, y quizá también de la literatura, consistente en estudiar las Cantigas de Santa María a través de las, mucho más numerosas, escenas de milagros ${ }^{3}$.

Las dos versiones de la Crucifixión y del Juicio Final que vamos a considerar en las Cantigas $^{4}$ (Figs. 1-4 y 9-10) ponen en duda la aparente evolución de la iconografía cristiana medieval de Occidente desde un arte del siglo XIII, la época clásica del Gótico, lleno de serenidad y preocupación por el dogma, que habla sobre todo a la inteligencia y a la fe, y un arte tardogótico, más sensual y narrativo, con insistencia en el dramatismo, que se dirige ante todo a la sensibilidad religiosa del espectador.

De las imágenes que voy a estudiar aquí sólo he encontrado su parangón en otras obras europeas de los siglos XIV y XV, en los momentos finales de la Edad Media. Conviene señalar, además, que su presencia, en las Cantigas de Santa María ${ }^{5}$, constituye un hecho aislado,

${ }^{3}$ La obra que por mucho tiempo pareció definitiva de J. Guerrero Lovillo (Las Cantigas. Estudio arqueológico de sus miniaturas, Madrid, 1949) ciñe su investigación a un estudio de las técnicas materiales que presentan las imágenes pero se refiere al arte de las Cantigas (Escorial, ms. T.I.1.) diciendo que desconoce «las especulaciones de los teólogos y es absolutamente indiferente a ... los místicos... Estamos muy lejos de los intrincados conceptos de los teólogos. Todo rezuma una sencillez y una ingenuidad deliciosas, tanto desde el punto de vista literario como del artístico...su arte es un arte estrictamente civil, pese a ser un Cancionero religioso» (p. 25). Espero demostrar en mi trabajo la complejidad teológica y el conceptualismo elaborado que preside el arte de las Cantigas. Posteriormente (ya que conocía y cita mis trabajos, uno de ellos aún en prensa) M. V. Chico Picaza en «Una nueva iconografía trinitaria en el códice rico de las cantigas de Alfonso X el Sabio (Escorial T.I.1.)», Boletín de la Real Academia de Bellas Artes de San Fernando, 56 (1983) pp. 215-223, plantea una interesante interpretación teológica de las miniaturas de otra de las cantigas de loor. Sobre la importancia que tuvo en su momento el libro de Guerrero Lovillo véase la recensión que le dedicó L. M. J. Delaissé en Scriptorium, V (1951) 168-169. N. Aita (O codice florentino das Cantigas do Rey Affonso o Sabio, Rio de Janeiro, 1922) hace importantes observaciones sobre los valores literarios de las cantigas de loor y sobre sus antecedentes litúrgicos que creo merecen una nueva lectura (pp. 34, 40 y ss.).

${ }^{4}$ Este estudio se refiere al llamado «códice rico» de las Cantigas de Santa María cuya primera parte se guarda en la Biblioteca del monasterio de El Escorial (ms. T.I.1.) pero que se prolonga en una segunda parte, inacabada, en la Biblioteca Nazionale de Florencia (ms. B. R. 20). De ambos códices existen las siguientes ediciones facsímiles realizadas por Edilán: Alfonso X El Sabio, Cantigas de Santa María, 2 vol., Madrid, 1979 (el volumen complementario titulado El códice rico de las Cantigas. Ms.T.I.1 de la Biblioteca de El Escorial, lleva estudios de M. López Serrano, J. Filgueira Valverde, R. Lorenzo Vázquez, J. Guerrero Lovillo y J. M. Llorens Cistero); y Alfonso X El Sabio, El códice Florentino de las Cantigas, Madrid, 1992, cuyo volumen complementario lleva estudios de M. V. Chico Picaza y A. Domínguez Rodríguez. Existen, además, otros dos códices originales del «scriptorium» regio de los que el uno carece de miniaturas (Madrid, Biblioteca Nacional, ms. 10.069) y el otro (Escorial, ms. b. I. 2., llamado «códice princeps») posee cuarenta y dos en las que, tras los retratos preliminares del rey, se representan únicamente músicos con diversos instrumentos musicales. A partir de aquí cuando mencione las miniaturas de las Cantigas me referiré simplemente al «códice rico» si es la primera parte (Escorial, ms. T.I.1.) y llamaré códice florentino a la segunda inacabada de la Biblioteca Nazionale de Florencia (ms. B. R. 20).

5 Antes del Congreso de Nueva York ya me había referido a la peculiaridad de las imágenes evangélicas de las Cantigas . Así en A. Domínguez Rodríguez, «Imágenes de un rey trovador de Santa María (Alfonso X en las Cantigas)», en $I l$ Medio Oriente e l'Occidente nell'Arte del XIII secolo, a cura di Hans Belting, Bologna, 1982, p. 233 (vol. II de «Atti del $\mathrm{XXIV}^{\circ}$ Congresso Internazionale di Storia dell'Arte» celebrado en Bologna en septiembre de 1979). Posteriormente añadí datos sobre las imágenes evangélicas en EADEM, «Poder, ciencia y religiosidad en la miniatura de Alfonso X el Sabio. Una aproximación», en Fragmentos, 2 (1984) en donde escribo de nuevo sobre la Virgen de la Humildad y el Juicio Final de las Cantigas (pp. 42-46); EADEM, pp. 47-54 en «El Libro de los Juegos y la miniatura alfonsí» en Alfonso X El Sabio, Libros de Ajedrez, Dados y Tablas, volumen complementario de la ed. facsímil, Madrid, 1987; EADEM, «La ilustración de los manuscritos» en Historia ilustrada del Libro Español, de H. Escolar (ed.), vol. I, Los manuscritos españoles, Madrid, 1996, pp. 328-330. Últimamente me he dedicado al estudio en profundidad de algunas de esas imágenes evangélicas comenzando por la del Árbol de Jesé. EADEM: «En torno al Árbol de Jesé (siglos XI-XIII). Tres ejemplos en las Cantigas de Santa María», en Cobras e Som. A Colloquium on the Text, Music and Manuscripts of the Cantigas de Santa María, de S. Parkinson (ed.), actas (en prensa) de un coloquio que tuvo lugar en Oxford (Somerville College) entre el 89 de julio de 1994. Desde uno de los tres ejemplos del Árbol de Jesé de las Cantigas he llegado a una nueva interpretación del famoso mural gótico de la catedral de Pamplona denominado (con discusiones) Árbol de Jesé: EADEM, «Del Árbol de Jesé de la catedral de Pamplona y su carácter trinitario», en Actas (en prensa) del Simposio sobre la Biblia en el Arte y en la Literatura, Pamplona, septiembre de 1997. 
$\mathrm{y}$, aparentemente, sin consecuencias inmediatas en las artes figurativas españolas bajomedievales ${ }^{6}$.

\section{La Crucifixión del siglo XIII y la «compassio Mariae»}

Como sabemos por los estudios de iconografía el arte del siglo XIII se caracteriza por una serenidad y una claridad intelectual que se dirigen a la fe y a la inteligencia del espectador. En la mayoría de las Crucifixiones del siglo XIII junto al Cristo crucificado aparecen a ambos lados la Virgen y San Juan en pie ${ }^{7}$. Se sigue en esta imagen el himno religioso tantas veces cantado «stabat Mater Dolorosa». El «stabat» latino significa estar en pie, erguida, única posición acorde con la dignidad de María y con la contención y serenidad del arte del XIII.

Un ejemplo, entre los muy numerosos posibles de citar estaría en el salterio de Blanca de Castilla $^{8}$, (Fig. 6) de hacia 1230, en donde vemos a la Crucifixión, dentro de una composición circular, en la que el dolor de la Virgen se expresa únicamente por el gesto de llevar su mano a la mejilla, cosa que hace también el apóstol San Juan ${ }^{9}$; en un medallón inferior aparece el Descendimiento, en el que la Virgen simplemente besa la mano de su Hijo. Se trata de mostrar la emoción contenida, la reserva de los sentimientos, mientras que a los lados aparecen la Iglesia y la Sinagoga que, como resultado de una larga tradición intelectual y simbólica, se representan con frecuencia en este lugar ${ }^{10}$.

Emile Mâle dejó establecido, además, que en el Gótico tardío, en un fenómeno que se iniciaría en el siglo XIV en Italia, por influencia de los franciscanos y sobre todo a partir de las «Meditationes vitae Christi» del Pseudo-San Buenaventura, el arte religioso adquiere un nuevo carácter pues se carga de emociones y sentimientos. El fiel que contempla la imagen religiosa o lee los textos piadosos ha de imaginar los dolores sufridos por Cristo durante la Pasión y los de su Madre paralelamente («compassio Mariae») ${ }^{11}$. Como consecuencia de estos nuevos sentimientos, en los que también influyeron los místicos, surgió un nuevo tipo de icono, que estudiara magistralmente Panofsky, la «imago pietatis» ${ }^{12}$.

\footnotetext{
${ }^{6}$ El ejemplo español más próximo al Juicio Final de las Cantigas es la pintura mural con este mismo tema del sepulcro de Miguel Sánchez de Asiaín (1357-1364) (Fig. 5) que, procedente de la catedral de Pamplona, se guarda en el Museo de Navarra. Esta pintura puede derivar, como ha estudiado M. C. Lacarra, por su cronología de alguno de los manuscritos del «Speculum Humanae Salvationis». Estos representan, como veremos, el mismo tipo de Juicio Final en fechas posteriores a las Cantigas, pero quizá resultaron más asequibles que el propio códice alfonsí pues este estuvo primero en la corte del rey Sabio y luego, por su testamento, en su capilla funeraria de la catedral de Sevilla. Sobre la pintura navarra Vid. M. C. Lacarra Ducay, Aportación al estudio de la pintura mural gótica en Navarra, Pamplona, 1974, pp. 308-325 y lams. 32-33 y figs. 57-63; EADEM, «Influencia de la escuela de Siena en la pintura navarra del siglo XIv. Los murales de la catedral de Pamplona», en Reales Sitios, 82 (1984) 65-72. EADEM, «Edad Media» en Museo de Navarra, Pamplona, 1993, p. 98; EADEM, «Pintura mural gótica en Navarra y su ámbito de influencia» en Revisión de Arte Medieval en Euskal Herría, Donostia, 1996, pp. 173-193.

${ }^{7}$ «Au XIIIe siècle, les artistes, en représentant la Crucifixion, se proposent beaucoup moins de nous attendrir sur les souffrances de l'Homme-Dieu que de nous remettre en mémoire .... grandes idées dogmatiques, dont la première est que Jésus-Christ est le nouvel Adam venu en ce monde pour effacer la faute de l'ancien...» (E. Mâle, «L'art religieux du XIIIe siècle en France, París, 1958, vol. II, p. 106). Vid. también L. Réau, Iconografía del arte cristiano. Iconografía de la Biblia. Nuevo Testamento, Barcelona, 1996, pp. 494-523; G. Schiller, Iconography of Christian Art, London, 1972, vol.II: The Passion of Jesus Christ, «The Crucifixion», pp. 88-164 y figs. 321-539.

${ }^{8}$ El Salterio se llama también de San Luis y Blanca de Castilla y es el ms. 1186 Rés. de la Biblioteca del Arsenal de París. Vid. Trésor de la Bibliothèque de l'Arsenal, París, 1980, nº 265.

${ }^{9}$ Sobre el origen y la presencia de estos dos personajes al pie de la cruz Vid. D. C. Shorr, «The Mourning Virgin and Saint John» en The Art Bulletin, XXII (1940) 61-69.

${ }^{10}$ Mâle, ibidem., pp. 106-112: la Crucifixión del siglo xiII expresa otra idea dogmática: que en el mismo día de la Crucifixión Cristo dió nacimiento a la Iglesia mientras abolía la Sinagoga. Réau, ibidem, pp. 507-508. Schiller, ibidem.

1 E. Mâle, L'art religieux de la fin du Moyen Age en France, París, 1995, pp. I-III, 5-6, 122-123.

12 E. Panofsky, «Imago Pietatis». Ein betrag zur Typensgeschichte des «Schmerzensmanns» und der «Maria medriatrix», en Festschrift für Max J. Friedländer zur 60 Geburstag, Leipzig, 1927, 261-308.
} 
Sin embargo, y dando un rotundo mentís a todo lo expuesto, en una miniatura de la Cantiga 50 del códice T.I.1. (Fig. 1-2) escurialense vemos a María a los pies de su Hijo y abrazada a la cruz, arrodillada y vencida por el dolor, en el mismo momento en que están crucificando a Cristo todavía vivo. Además, y por si fuera poco, vemos en la Cantiga 140 (Fig. 3-4), en una escena de la Crucifixión, que está acompañada por dos grupos multitudinarios colocados a ambos lados de la misma, a la Virgen en el suelo, abrazando los pies de su Hijo ${ }^{13}$.

Ambas Cantigas, 50 y 140, son cantigas decenales, que por lo general el texto titula «de loor» y que comúnmente se ocupan de alabar a María, que se diferencian de las otras, mucho más numerosas, dedicadas a contar los milagros de la Virgen. Pero en estas cantigas decenales el «texto verbal» ${ }^{14}$ no es suficiente para explicar el «texto pictórico» y hay que recurrir a los métodos comparativos de la Historia del Arte para poder interpretar las miniaturas representadas ${ }^{15}$.

¿Cómo pudo llegar una escena visual tan avanzada, que el texto de la propia cantiga no explica, a la corte alfonsí? El creador de estas imágenes fue un artista excepcional o tuvo un mentor de gran audacia religiosa que le sugirió los nuevos temas?

Los ejemplos parangonables por mi conocidos, en la pintura y en la miniatura, son todos del siglo XV, siendo el más parecido una pintura del Maestro de Flémalle ( Robert Campin), la Cru-

${ }^{13}$ Como exponente de la excepcionalidad de estas imágenes del Códice rico de las Cantigas léase la cita siguiente:»En todas las Crucifixiones anteriores a finales del siglo XIII, la Virgen y san Juan, la madre y el discípulo preferido a quien Cristo agonizante había confiado y encomendado uno al otro (Juan 19:26), forman pareja, uno a cada lado de la cruz, como el Sol y la Luna, el Buen y el Mal Ladrón, el Lancero y el Portaesponja. El lugar tradicional de la Virgen es a la derecha de su Hijo crucificado mientras que san Juan se situa a la izquierda» (Réau, ibidem, p. 518). Pero además existen en los mismos códices de las Cantigas otras crucifixiones que en otra ocasión analizaremos: o bien con el crucifijo aislado (cantigas $30,113,170,190$ ) o bien con el crucificado entre la Virgen y San Juan en la disposición habitual del siglo xIII (f. 36 del códice florentino).

${ }^{14}$ La cantiga 50 dice lo siguiente, en traducción al castellano del lenguaje gallego original de la misma:

«Esta es de loor de Santa María que muestra por qué razón encarnó Nuestro Señor en ella. / Ningún hombre por nada debe dudar esto: que Dios en una Virgen vino a tomar carne. Y dudar no debe por lo que os diré, porque si así no fuese, no seríamos capaces de ver al rey que nos ha de juzgar cuerpos y almas; yo sé que Jesu-Cristo habrá de venir a juzgarnos. / Ningún hombre para nada debe dudar esto... / De otra manera no podríamos ver a Dios; nunca podrían su hechos inspirarnos amor y duelo si El fuese tal que nuestros ojos no alcanzaran a verlo. / Ningún hombre por nada debe dudar esto... / Por esto quiso El bajar a la tierra sin dejar de ser uno ni sufrir mengua en su poder; y quiso por nosotros tomar carne en una Virgen, y aún más se dejó matar por nosotros. / Ningún hombre por nada debe dudar esto... / Por todo ello, en cuanto que Dios, Padre y Creador nuestro le debemos amor, y en cuanto que hombre seremos capaces de sufrir y sentir pena por todo lo que Él soportó por nosotros. / Y debemos amar a la Santa Virgen en la que El se encerró, en la que encarnó y a la que eligió por madre, porque gracias a ella pudo mostrarnos todas las cosas que os acabo de contar. / Ningún hombre por nada debe dudar esto».

Traducción tomada de L. Beltrán, Las cantigas de loor de Alfonso X el Sabio. Estudio y traducción, Madrid, 1990, pp. 131-133.

El texto de la cantiga 140 es igualmente genérico y no justifica en absoluto, en mi opinión, la elección de sus miniaturas, pues dice así:

«De loor de Santa María. / Dados le sean a Santa María honrados loores. / Loemos su mesura, su honor y su apostura y su juicio y su cordura mucho más de cien mil veces. / Dados le sean a Santa María... / Loemos su nobleza, su honra y su alteza, su merced, su franqueza y sus preciadas virtudes. / Dados le sean a Santa María... / Loemos su lealtad, su consuelo y su bondad, su socorro y su verdad con loores muy cantados. / Dados le sean a Santa María... / Loemos su buen criterio, su consejo y su advertencia, su bien, su lección y sus gracias muy granadas. / Dados le sean a Santa María... / Loándola, roguémosle que con arrojo nos valga en la batalla del mundo que nos pone a prueba y en la del demonio. / Dados le sean a Santa María...»

Traducción de L. Beltrán, ibidem, pp. 151-152.

${ }^{15}$ El texto de cada cantiga de loor no justifica en absoluto la imagen evangélica ya que esta era susceptible de ser interpretada con otras variantes. No hay unas reglas que expliquen la interrelación texto-imagen. Cfr. L. Beltrán, ibidem., que en pp. 40 y ss., y 140 y ss. cree poder explicar las imágenes de las cantigas 50 y 140 por el texto escrito. Sin embargo la cantiga 360 de la edición de W. Mettman (Alfonso X El Sabio, Cantigas de Santa María, vol. III, Madrid, 1989, pp. 307. 9), cuyo texto procede de uno de los códices sin miniaturas, se refiere a los siete dolores de la Virgen cantando sus sentimientos dolorosos. 

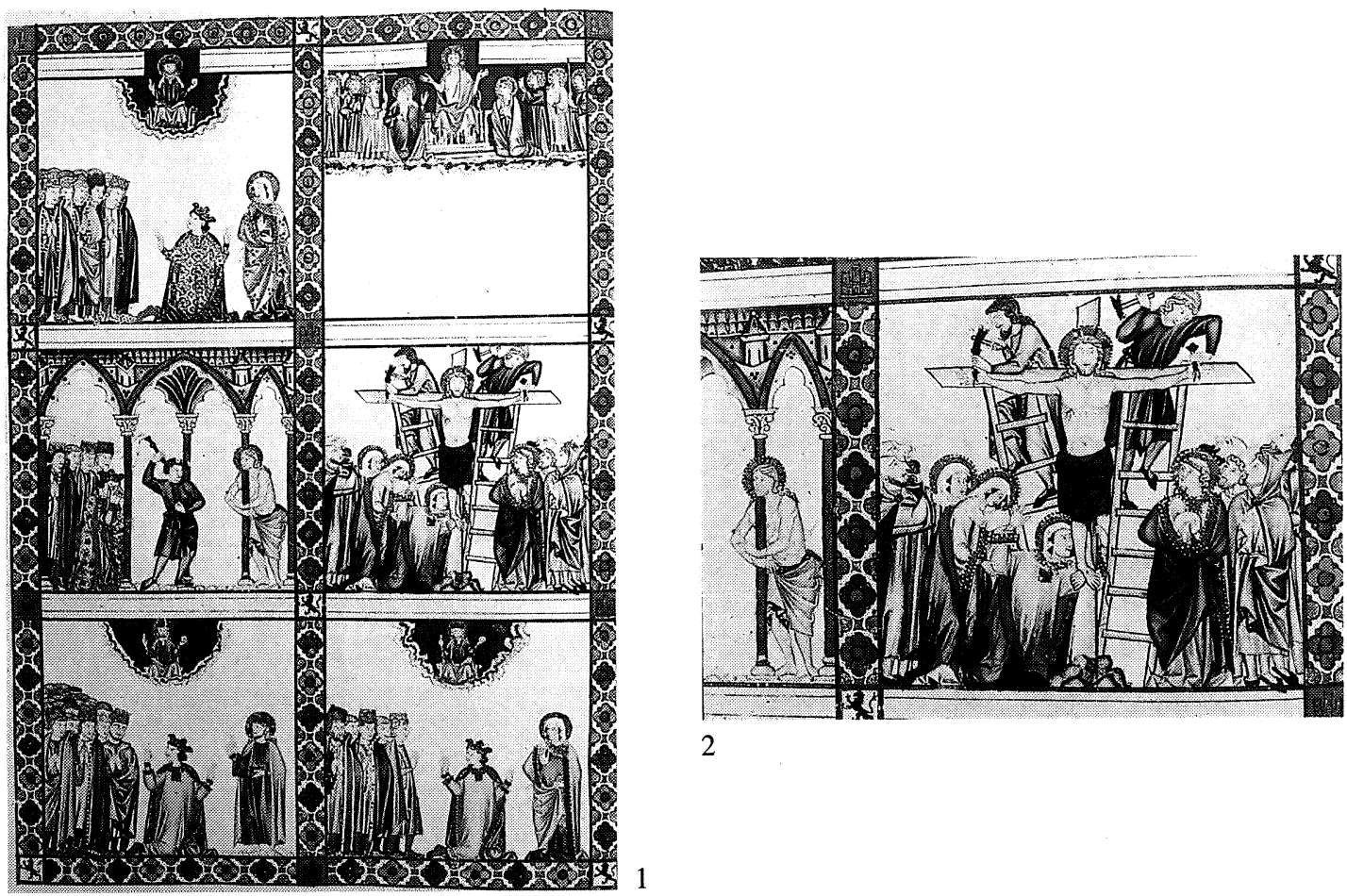

2
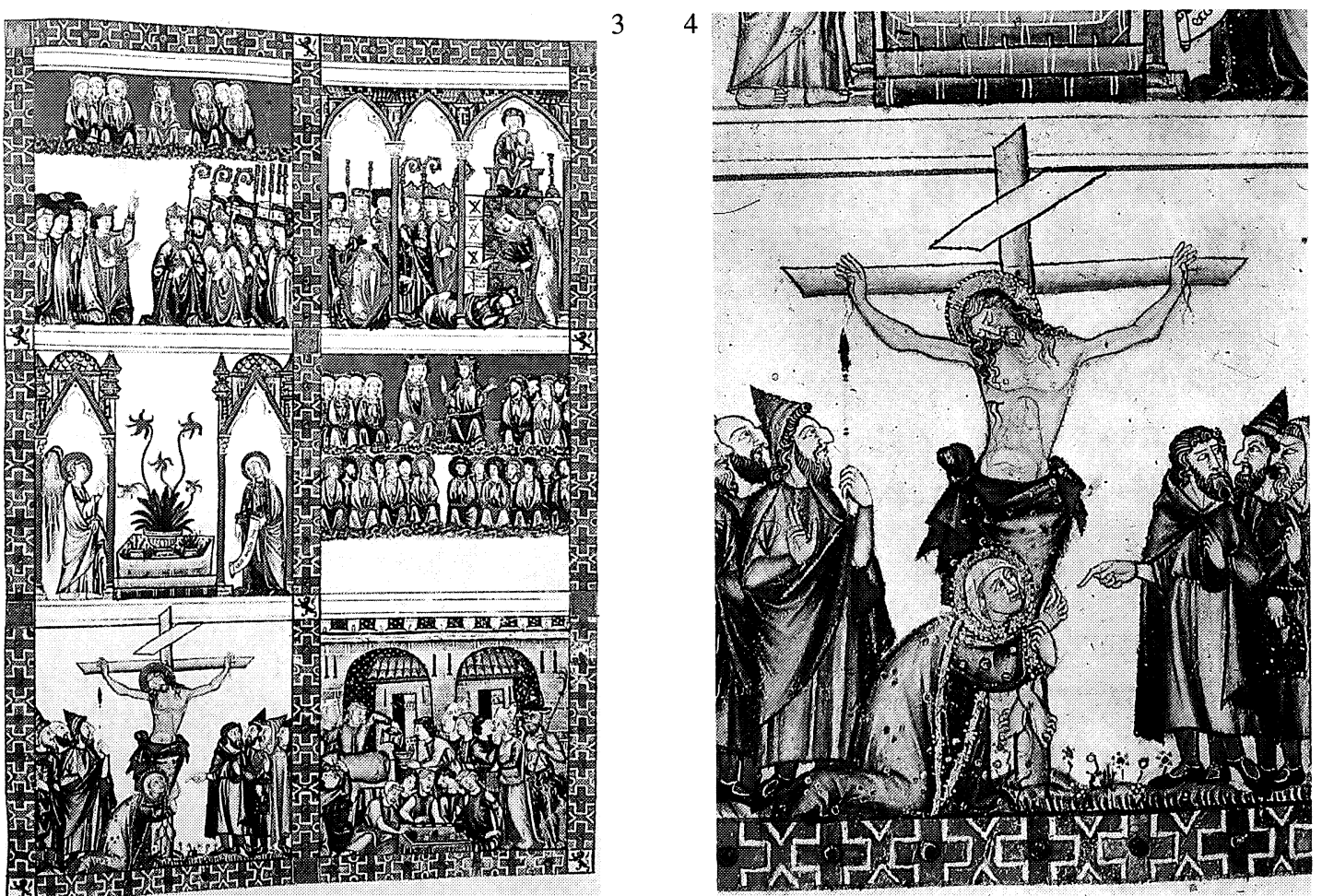

Figs. 1 y 2. Crucifixión, conjunto y detalle, Cantiga 50.

Figs. 3 y 4. Conjunto y detalle. Cantiga 140. Cantigas de Santa María, códice rico (ms. T.I.1.) El Escorial, Biblioteca del Monasterio. 
cifixión del Museo de Berlín (c. 1440) en la que al pie del Crucificado se sitúan San Juan, las tres Marías y la Virgen -ésta última arrodillada y abrazada a la cruz ${ }^{16}$.

Existe además una miniatura cercana en el espíritu, aunque no literal en la imagen, en las famosas Horas de Rohan (ms. lat. 9471, f. 135, París, Bibliothèque Nationale) en donde, al pie de la cruz desnuda, la virgen desmayada es sostenida por San Juan, estando María en actitud de derrumbarse sobre su Hijo muerto y tumbado en el suelo. Se trata de una obra maestra del expresionismo gótico y de uno de sus principales representantes,el gran Maestro de las Horas de Rohan ${ }^{17}$.

Puedo mencionar, además, otra miniatura de mayor similitud iconográfica, aunque posterior en el tiempo, en el Libro de Horas del Caballero Rollin de hacia 1475-85 (ms. Res. 149, f. 53v., Madrid, Biblioteca Nacional) (Fig. 7), en donde la Virgen agachada en el suelo se abraza a la cruz desnuda, clavada en tierra, que constituye una más de las «Arma Christi» que la rodean ${ }^{18}$.

Todas estas imágenes, en las que la Virgen se derrumba o se desmaya al pie de la Cruz, representan, con distintas modalidades, un sentimiento común, la «compassio Mariae», o pasión de la Virgen paralela a la de su Hijo, que constituye el núcleo argumental del famoso Descendimiento de Van der Weiden en el Museo del Prado, de hacia 1430-32, en el que la Virgen aparece desmayada y en disposición paralela al cuerpo de su Hijo muerto, y cuya iconografía ha recibido una interpretación excepcional de Otto von Simson ${ }^{19}$ cuyo estudio, además de inspirar nuestro título, nos va a dar numerosas pautas para profundizar en este tipo de imágenes.

Después del Concilio de Trento se mantiene, con pocas excepciones, a la Virgen en pie junto a la cruz, y será a la Magdalena a quien veamos, en ocasiones, acuclillada y abrazada al madero de la $\mathrm{Cruz}^{20}$ como, por ejemplo, en la Crucifixión de El Greco en el Museo del Pra$\mathrm{do}^{21}$.

Habría que rastrear en la miniatura de los siglos XII y XIII, para encontrar otros posibles ejemplos quizá anteriores, o al menos coetáneos, a las Cantigas. Esta búsqueda, ha resultado hasta ahora infructuosa, po lo que me he decidido a publicar el estado actual de mis investigaciones.

${ }^{16}$ G. Schiller, Iconography of Christian Art, vol. 2, London, p. 158 y fig. 523: recoge la imagen y la describe sin referirse a la figura arrodillada que, en mi opinión, es la Virgen y no la Magdalena.

${ }_{17}$ M. Meiss y M. Thomas, The Rohan Book of Hours, London, 1973, p. 14 y n. ${ }^{\circ}$ 57; el puesto del Maestro de las Horas de Rohan en los orígenes de la pintura flamenca ha sido establecido por E. Panofsky, Early Netherlandish Painting.Its Origins and Character, Nueva York, 1971, vol. I, pp. 74.

${ }^{18}$ A. Domínguez Rodríguez, Libros de Horas del siglo XV en la Biblioteca Nacional, Madrid, 1979, p. 17 y EADEM, Iconografía de los Libros de Horas del siglo xV de la Biblioteca Nacional, Madrid, 1993, tom. II, pp. 806-7 (se trata de la tesis doctoral del año 1973 publicada sin modificaciones por el Servicio de Reprografía de la Universidad Complutense).

19 O. G. von Simson, «Compassio and Co-redemptio in Roger van der Weiden's Descent from the Cross» en Art Bulletin, 35 (1953) 9-16. Más recientemente A. Châtelet, «El Descendimiento de la cruz de Rogier Van der Weiden» en AAVV, Obras maestras del Museo del Prado, Madrid, 1996, pp. 71-85.

${ }^{20}$ No aparecen imágenes similares en A. Derbes, Picturing the Passion in Late Medieval Italy. Narrative Painting, Franciscan Ideologies and the Levant, Cambridge, 1996. Ni tampoco en H. Van Os, The Art of Devotion in the Late Middle Ages in Europe. 1300-1500, Amsterdam, 1994. Tampoco aparecen, por descontado, en los tratados de iconografía arriba citados de E. Mâle, L. Réau ni tampoco en G. Schiller (Vid. supra). Ver más adelante en nota dos ejemplos relativamente similares en los que la Virgen aparece desmayada mientras que en las Cantigas se la ve derrumbada, pero consciente, y abrazada a la cruz.

${ }^{21}$ H. E. Wethey, El Greco y su escuela, Madrid, 1967, vol. II, pp. 65-66. En la Crucifixión posterior a Trento la Virgen se representará en pie e incluso sin lágrimas pues se repetían las palabras de S.Ambrosio:»Stantem illam lego, flentem non lego» (Leo en el Evangelio que ella está de pie, pero no que haya llorado). Por este motivo en Roma se mandaron quitar muchos cuadros representando a la Virgen desvanecida en el Calvario. Sigo a E. Mâle, El Barroco. Arte religioso del siglo XVII en Italia, Francia, España, Flandes, Madrid, 1985, p. 30. 


\section{«Compassio»y «co-redemptio Mariae» en la Crucifixión}

Los sentimientos de María al pie de la cruz han sido objeto de meditaciones piadosas desde los comienzos del cristianismo pero desde el siglo XII, sin embargo, estas reflexiones tomaron un nuevo significado. Para Wilmart es el siglo XII, y no el XIII como había escrito Émile Mâle, el que supone el comienzo del pensamiento gótico ${ }^{22}$, en los mismos momentos en que en Normandía se inician las novedades técnicas de la arquitectura gótica.

Ya Anselmo de Canterbury (muerto en 1109) meditó ampliamente sobre los sufrimientos de María al pie de la cruz ${ }^{23}$, aunque fue San Bernardo de Claraval (1090-1153) el padre de la idea de la «compassio Mariae». Comparando este último autor la Pasión de Cristo con la «Compassio Mariae» llegó a la conclusión de que María ha sufrido más que los mártires dado que tuvo una agonía en espíritu mayor de la que puede significar cualquier sufrimiento físico ${ }^{24}$.

Pero fue Ernaldo de Chartres (muerto hacia 1160), contemporáneo y amigo de San Bernardo, quien, en su tratado «De laudibus Beatae Mariae Virginis», aplica por primera vez a la teología de la Redención la yuxtaposición de «passio» y «compassio». Ernaldo describe la «Compassio Mariae» como un verdadero sacrificio, conjunto al de Cristo y paralelo en cada detalle a la Pasión de su Hijo ${ }^{25}$.

En el siglo XIII las meditaciones sobre la compasión de María ganan en realismo, en frecuencia y en popularidad. Paralelamente la idea de la «Compassio Mariae» recibe definición teológica cuando San Alberto el Grande (muerto en 1280) señala la dignidad de María como «co-adjutrix» en la obra de la Redención porque perseverando sóla en el Calvario recibió en su corazón las llagas que Cristo sufrió en su cuerpo cumpliéndose la profecía de Simeón: «y una espada atravesará tu alma ...» (Lucas, 2, 35). San Alberto recoge las ideas de San Bernardo arriba mencionadas y añade: Cristo quiso hacer a su Madre partícipe de los beneficios de la Redención ${ }^{26}$.

Con el misticismo afectivo de San Francisco y sus seguidores se intensificó de un modo creciente la tendencia a identificar la intervención de María en la Redención con su participación en la Pasión. Pero son los escritos de San Buenaventura (1221-1274) los que señalan claramente la dramática coordinación de «passio» $\mathrm{y}$ «compassio». Al comentar la posición de María en el Calvario la describe como la mujer fuerte del Libro de los Proverbios $(31,10)$. La Virgen al pie de la cruz acepta la voluntad divina. Incluso ofrece el fruto de su vientre por la Redención del Hombre. María es vista como el sacerdote del sacrificio, heroica figura que San Buenaventura com-

${ }^{22}$ A. Wilmart, Auteurs spirituels et textes dévots du Moyen Age Latin, Paris, 1932, pp. 250 y ss. Citado por von Simson, p. 11.

${ }_{23}$ Migne, Patrologia latina, CLVIII, col. 920 y Wilmart, cap. 23. Citado por Simson, p. 11.

24 «Dominica infra Octavam Assumptionis B. V. Mariae Sermo»,en Migne, Patrologia Latina., CLXXXXIII, col. 1012. Citado por Von Simson, p. 11. Para la versión latina y castellana Vid. S. Bernardo, Obras completas, IV, B.A.C., Madrid, 1986, pp. 413-14: «En efecto, cuando aquel Jesús ... expiró, el hierro cruel abrió su costado, sin perdonarle aún después de muerto. A él ya no podía hacerle mal alguno, ni llegó a tocar su alma, pero si atravesó la tuya. Su alma ya no estaba allí, la tuya, en cambio, no podía ser arrancada de aquel lugar. Sí, la punzada de dolor atravesó tu alma, y con toda razón te llamamos más que mártir, ya que tus sentimientos de compasión superaron las sensaciones del dolor corporal... ¿Qué clase de hombre eres que te extrañas más de la compasión de María que de la pasión del hijo de María? Este murió en su cuerpo, ¿y ella no pudo morir en su corazón?.»

${ }^{25}$ Ernaldo de Chartres, Patrologia latina, CLXXXIX, cols.1726 y ss. Dice lo siguiente: «...omnino tunc erat una Christi et Mariae voluntas, unumque holocaustum ambo pariter offerebant Deo: haec in sanguine cordis, hic in sanguine carnis....In faciem filiii se opposuerat mater et gladio doloris animae ejus infixo, vulnerabatur spirito et concrucifigebatur affectu. Quod in carne Christi agabant clavis et lancea, hoc in mente ejus compassio naturalis et affectionis maternae angustia». Citado por Von Simson, p. 12.

${ }^{26}$ Alberto Magno, Opera omnia, XXXVII, París, 1898, pp. 81 y 214 y ss, «Quaestiones super Evang., cap. 43 y 149,2. Citado por Von Simson, p. 12. 
para con Judith y con Abraham presto a sacrificar su propio hijo ${ }^{27}$. Pero el Santo señala que paralelamente la Virgen sufre terriblemente aunque expresa su acuerdo con la Crucifixión ${ }^{28}$.

Los teólogos del siglo XIII señalaban el «Stabat Mater» como ejemplo de sus enseñanzas: en pie bajo la Cruz la actitud de María se reviste de dignidad sacerdotal, mostrando un consentimiento heroico y humilde al divino plan de Salvación. Por ello aunque existen representaciones tempranas de la Virgen desmayada ${ }^{29}$, e incluso en las Cantigas de la Virgen arrodillada y abrazada a la cruz desnuda, la iconografía del «Stabat Mater» predomina con mucho.

En los escritos de S. Buenaventura se exponía un dilema en la expresión de esas emociones duales sentidas por María al pie de la cruz y los pintores podían elegir entre ambas. En las dos Crucifixiones de las Cantigas que aquí estudiamos (50 y 140) el anónimo creador de las imágenes, fuera el propio pintor o un mentor religioso del artista, se quiso inspirar en la segunda modalidad, que como hemos dicho es en el siglo XIII muy poco frecuente ${ }^{30}$. San Buenaventura al explicar que la Virgen se transformó en una casi igual a Cristo sigue a Hugo de San Víctor diciendo que el poder del amor transforma al amante en una imagen del amado ${ }^{31}$. De acuerdo con el misticismo gótico el poder transformador del amor de Cristo opera sobre todo por medio de la «compassio». En la biografía de San Francisco se señala que fue «su tierna compasión la que le transformó en una imagen del crucificado» ${ }^{32}$.

El emocionalismo religioso de los siglos siguientes concibió la dignidad teológica de la «coredemptrix» como fruto de su «compassio», trazando una unión mística entre los dos sacrificios que tuvieron lugar en el calvario, la «passio» y la «compassio». A partir de aquí se yuxtapondrá una elaborada y detallada Pasión de la Virgen en paralelo a cada una de las estaciones de la $\mathrm{Pa}$ sión de Cristo.

El «Speculum Humanae Salvationis» (Fig. 8), obra muy representativa de los siglos XIV y $\mathrm{xv}$, expone en uno de sus capítulos las siete estaciones de la Pasión de Cristo y a continuación en otro los siete dolores de María. El paralelismo entre la Redención y la Corredención es explícito al señalarse por ejemplo: «En el capítulo anterior hemos oído como Cristo venció al dia-

${ }^{27}$ S. Buena Ventura, De Septem Donis Spiritus Sancti, Collatio VI (Opera omnia, XXXVII, París, 1898, pp.81 y 214 y ss.: Citado por Von Simson, 12.

${ }^{28}$ S. Buenaventura, ibidem: «Beata Virgo compatiebatur ei maxime, sed ex altera parte placebat ei, quod pro nobis traderetur». Citado por Simson p. 12.

${ }^{29}$ Von Simson (p. 13) se pregunta si la iconografía del «spasimo» o desmayo de la Virgen tuvo su origen en Bizancio. Señala, al menos un ejemplo en la Crucifixión del muro norte del monasterio de Sopocani, de hacia 1265, aunque indica otro ejemplo occidental en un Misal de la Biblioteca de Toulouse (ms. 103, f. 133v.). Vid. Musée des monuments français: L'art médiéval yougoslave, París, s.f., pl. 36, y Les trésors des bibliothèques de France, V (1935) pl. XIX.

${ }^{30}$ En ocasiones anteriores he expresado mi convencimiento de que estas imágenes evangélicas de las Cantigas se han inspirado en el franciscanismo. Así en mi trabajo ya citado «Imágenes de un rey trovador...» escribí: «la fecha temprana con que vemos estos temas en las Cantigas me hace pensar no tanto en la genialidad de un pintor sino más bien en un escritor que inspirara al rey la nueva temática religiosa o la expresión de unos sentimientos nuevos» (ibidem, p. 234); «en el caso de estas miniaturas alfonsíes podría tratarse de un escritor, quizá el franciscano español Fray Juan Gil de Zamora, probable discípulo de San Buenaventura que como preceptor del príncipe don Sancho, hijo de Alfonso X, empezó a gozar de gran prestigio en Castilla. Para el propio Alfonso escribió este franciscano un «Officium almifluae Matris almae regis Jesu» que narra en himnos y antífonas casi toda la vida de la Virgen» (ibidem, p. 234). También en mi «Iconografía evangélica...» señalé: «la iconografía de las escenas evangélicas responde a una nueva religiosidad, anticipadora de la que en el Trecento se difundirá desde Italia por todo Occidente, y que puede derivar de Bizancio aunque su raiz entronca con el Franciscanismo. El enlace con Alfonso X podría estar en el franciscano Fray Juan Gil de Zamora» (p. 43). Vid. también mi trabajo: «Poder, ciencia y religiosidad...», p. 43).

${ }^{31}$ S. Buenaventura, Opera omnia, IX, p. 695: «Vis amoris amantem in amati similitudinem transformat». Citado por Simson, p. 13.

32 «Dum...affectus compassiva teneritudine in eum transformaretur, cui ex caritate nimia crucifigi complacuit». Este pasaje procede de la Legenda majus de S. Buenaventura (cap. 13) pero constituye la lección IV en la Fiesta de los Estigmas del Breviario Romano. Citado por Simson, p. 13. 

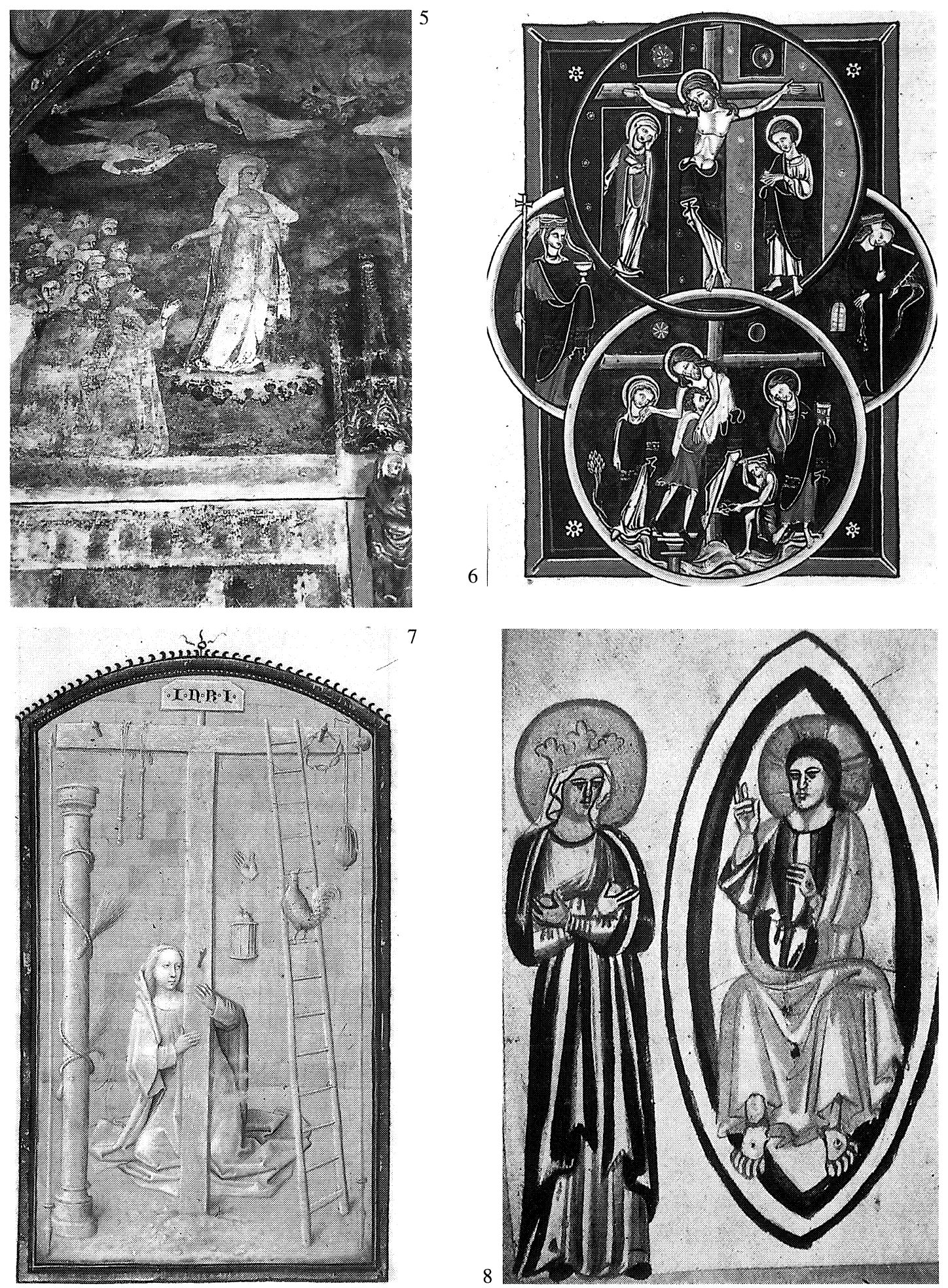

Fig. 5. Juicio final, detalle, pintura del sepulcro de Miguel Sánchez Asiaín. Pamplona, Museo de Navarra.

Fig. 6. Crucifixión. Salterio de Blanca de Castilla. París, Biblioteca del Arsenal.

Fig. 7. Crucifixión. Libro de Horas del Caballero Rollin (ms. Res, 149, f. 53v.). Madrid, Biblioteca Nacional.

Fig. 8. La Virgen ante el Juez. Speculum Humanae Salvationis. Toledo, Catedral. 
blo a través de su Pasión, ahora vamos a oir en el capítulo siguiente como María venció al diablo a través de su Compasión» ${ }^{33}$. Sin embargo, ninguno de los manuscritos iluminados del «Speculum Humanae Salvationis» por mí conocidos tienen una imagen de la Virgen al pie de la cruz expresando la «compassio Mariae» con un desmayo, derrumbamiento o desvanecimiento como en el «códice rico» de las Cantigas y otras obras de iconografía similar que mencionaremos ${ }^{34}$.

Aunque, como hemos visto, el concepto de la Compasión de María es muy anterior, el término corredención parece haberse acuñado en el siglo XIV y desde el siglo XV los conceptos «coredemptio» $\mathrm{y}$ «compassio» son inseparables ${ }^{35}$

\section{La imagen de la corredención de María en el Juicio Final}

El Juicio Final característico del Gótico suele aparecer en el tímpano de alguna de las portadas de las grandes catedrales, desde el siglo XII. La figura central que preside la escena en este Juicio Final es Cristo entronizado, mostrando las llagas del costado, pies y manos. Es la visión de Mateo que desde el siglo XII constituye una nueva fórmula frente al Pantocrator del Juicio Final románico.

Este nuevo Juicio Final expresa maravillosamente el nuevo enfoque del cristianismo. El Juez ya no es el Pantocrator, en toda su majestad y «terribilitá», sino que se ha humanizado. Desde el siglo XII los artistas prefieren seguir el Evangelio de San Mateo (XXIV y XXV), mejor que el Apocalipsis, para reproducir la escena del Juicio Final. Aunque el texto del evangelista es menos fulgurante resulta más accesible para la gente sencilla.

En S. Mateo, Dios ya no es la enorme piedra preciosa refulgente cuyo brillo no se puede sostener con la mirada sino que es el Hijo del Hombre que aparece sobre su trono tal como fue durante su estancia en la tierra. Un capítulo sobre la resurrección de los muertos, de la primera Epístola de San Pablo a los Corintios (XV, 52), y el propio Apocalipsis proporcionaron algunos detalles secundarios. Estos pasajes bíblicos, interpretados por los teólogos y enriquecidos por la imaginación popular, dieron lugar a las bellas escenas del Juicio Final que adornan casi todas las catedrales del siglo XIII.

\footnotetext{
${ }^{33}$ Von Simson, p. 13.

${ }^{34}$ La obra básica sobre el «Speculum Humanae Salvationis» sigue siendo la de J. Lutz y P. Perdrizet (ed.), Speculum Humanae Salvationis, 2 vols., Leipzig, 1907. Vid. también M. R. James y B. Berenson, Speculum Humanae Salvationis, Oxford, 1926; E. Breitenbach, Speculum Humanae Salvationis. Eine Typengeschichtliche Untersuchung, Strassbourg, 1930; E. Silber, «The reconstructed Toledo Speculum Humanae Salvationis: the Italian Connection in the early Fourteenth Century» en Journal of the Warburg and Courtauld Institute, 43 (1981) 33-51 ; Speculum Humane Salvationis, ed.facsímil del códice Cremifanensis 243 del monasterio de Kremsmünster y volumen complementario de W. Neumüller, Graz, 1972; H. Appuhn, Heilsspiegel. Die Bilder des mittelalterlichen Erbauunsbuches «Speculum Humanae Salvationis», Harenberg, Dortmund, 1981; K. W. Wirth, «Auf den Spuren einer frühen Heilsspiegel-Handschrift vom Oberrhein», en Jahrbuch des Zentralinstituts für Kunstgeschichte, 1 (1985) 115-204; B. Cardon, Manuscripts of the Speculum Humanae Salvationis in the Southern Netherlands (c.1410-1470). A Contribution to the Study of the 15th Century Book Illumination and of the Function and Meaning of Historical Symbolism, Lovaina, 1996.

${ }^{35}$ Von Simson, p. 14. Al estudiar estas imágenes de la Crucifixión y Juicio Final de las Cantigas no pretendo agotar el tema de la corredención de María en las Cantigas sino que he seleccionado dos imágenes precursoras por su cronología de la religiosidad bajomedieval y representativas de la modernidad de los «saberes» alfonsíes. De hecho la cantiga 60 del códice rico se dedica a la contraposición de la Eva pecadora del Paraíso y el Ave de la salutación angélica en la Anunciación. La idea de María como nueva Eva lleva implícita su función de corredentera y ya aparece plenamente representada en las puertas de bronce de S. Miguel de Hildesheim de comienzos del siglo XI. Esta cantiga 60 ha sido ampliamente analizada por E. Guldan (Eva und Maria. Eine antithese als Bildmotiv, Graz-Köln, 1966, pp.58-59, 178-79 y pl. 39) en un amplio contexto desde los orígenes del tema. La misma cantiga ha sido considerada por T. Pérez Higuera (La nativité dans l'art médieval, París, 1996).
} 
El nuevo ordenamiento del Juicio Final aparece en el siglo XII, tras unos primeros tanteos, en forma monumental en las grandes portadas del Camino de Santiago (tímpano de la portada central de Santa Foie de Conques, de la catedral de Beaulieu y del Pórtico de la Gloria) pasando luego al Norte, a la región de l'île de France. En los edificios del Camino de Santiago vemos ya algunas de las escenas que compondrán el nuevo Juicio Final: Cristo mostrando sus llagas, ángeles llevando los Instrumentos de la Pasión, peso de las almas, separación de buenos y malos, paraíso e infierno. En el protogótico del Norte de Francia en la portada de la abadía de Saint-Denis, y más tarde en Laon y Chartres se añadieron dos nuevos personajes: a ambos lados del Juez aparecen la Virgen y San Juan como intercesores.

Los intercesores, la Virgen y San Juan, la madre y el discípulo bien amado de Cristo, que habían asistido a su muerte en la cruz, aparecen también junto al triunfador en el día de su gloria. Se les ve de rodillas, o ligeramente inclinados, con las manos juntas en actitud de súplica. Su presencia como intercesores ante el divino Juez infundía a los fieles confianza a pesar del miedo al Juicio Final.

Pero es en Chartres en donde la escena se ordena mejor en una composición de admirable claridad que se repite a lo largo del siglo XIII, con pequeñas variantes, en París, Poitiers, Bordeaux, Amiens ${ }^{36}$ y en las catedrales españolas de Burgos (Puerta de la Coronería (Fig. 11), y tímpano en el claustro) y León ${ }^{37}$.

Sin embargo en las cantigas 50 (Fig. 9) y 80 (Fig. 10) vemos un Juicio Final en el que la actitud de la Virgen, que sigue en su papel de mediadora, presenta importantes diferencias con las típicas versiones que aparecen en las catedrales góticas.

La escena del Juicio Final de las catedrales, serena y adecuada con el dogma, se carga de dramatismo en las representaciones de las Cantigas. Si bien el Juez es el mismo Cristo, mostrando sus llagas, y a los lados aparecen los ángeles llevando los Instrumentos de la Pasión, la actitud de María ha cambiado dejando su devota actitud en la que con las manos juntas suplica a su Hijo. En un dramático gesto la Virgen, que sigue arrodillada en presencia del Juez, abre el escote de su vestido y le muestra el pecho desnudo con que le alimentó siendo Niño. Aunque en la cantiga 50 aparece acompañada por San Juan, que en actitud de orante ejerce también de intermediario entre los hombres y la divinidad, sin embargo en la cantiga 80 este santo ha desaparecido y es únicamente ella quien comparte con su Hijo el protagonismo de la escena.

Esta versión del Juicio Final, en la que la Virgen abandona su actitud de simple orante para, mostrando el pecho desnudo, asumir ante su Hijo su papel de corredentora, es excepcional en el siglo XIII constituyendo los dos ejemplos de las Cantigas los únicos al parecer conocidos de este momento ${ }^{38}$ pero se difundirá en los siglos XIV y XV, apareciendo en primer lugar en los manus-

${ }^{36}$ He seguido por comodidad el breve estudio de E. Mâle, L'art religieux du XIIIe siècle..., pp. 398-438, pero sobre el tema del Juicio Final existe una amplia biblioografía que no voy a recoger aquí. Otra obra esencial: L.Réau, op. cit., supra., Tom. I, vol. II, pp. 749-779. La obra fundamental sobre el Juicio Final gótico es de Y. Christe: La vision de Mathieu (Matth.XXIV-XXV). Origines et développement d'une image de la seconde Parousie, Paris, 1973.

Vid. También P. Klein, «Eschatologische Portalprogramme der Romanik und Gotik» en Studien zur Geschichte der Europäische Skulptur im 12/13 Jahrhundert, de H. Beck y K. Hengevoss-Dürkop, tom. I, pp. 397-411 y tom. II $228-240$.

37 Vid. F. B. Deknatel, «The Thirteenth Century Gothic Sculpture of the Cathedrals of Burgos and Leon» en The Art Bulletin, XVII (1935) 243-388; A. Franco Mata, «Juicios Finales en la escultura monumental de las catedrales de Burgos y León y su área de influencia. Peculiaridades iconográficas hispanas» en De l'art comme mystagorie. Iconographie du Jugement dernier et des fins dernières à l'époque gothique, Actes du Colloque de la Fondation Hardt tenu à Genève du 13 au 16 février 1994, «Centre d'Études Supérieures de Civilisation Médiévale», Poitiers, 1996, pp. 175-198.

38 En M. Trens, María. Iconografía de la Virgen en el arte español, Madrid, 1946, pp.366-377 y fig.226 se clasifica como del siglo XIII un manuscrito de la catedral toledana con este tema que posteriormente ha sido coherentemente considerado como un ejemplar boloñés de fecha temprana del siglo XIV del «Speculum Humanae Salvationis». Vid. sobre este E. Silber, pp. 33-51 y pl. 1-10. El manuscrito de Soissons de los «Miracles de la Vierge» de Gautier de Coincy (1177-1236) presenta este mismo tipo de Juicio Final pero es del siglo XIV aunque Réau lo considera del XIII (Iconografía del arte cristiano...Nuevo Testamento, pp. 131-132, lo estudia fuera del Juicio Final). 


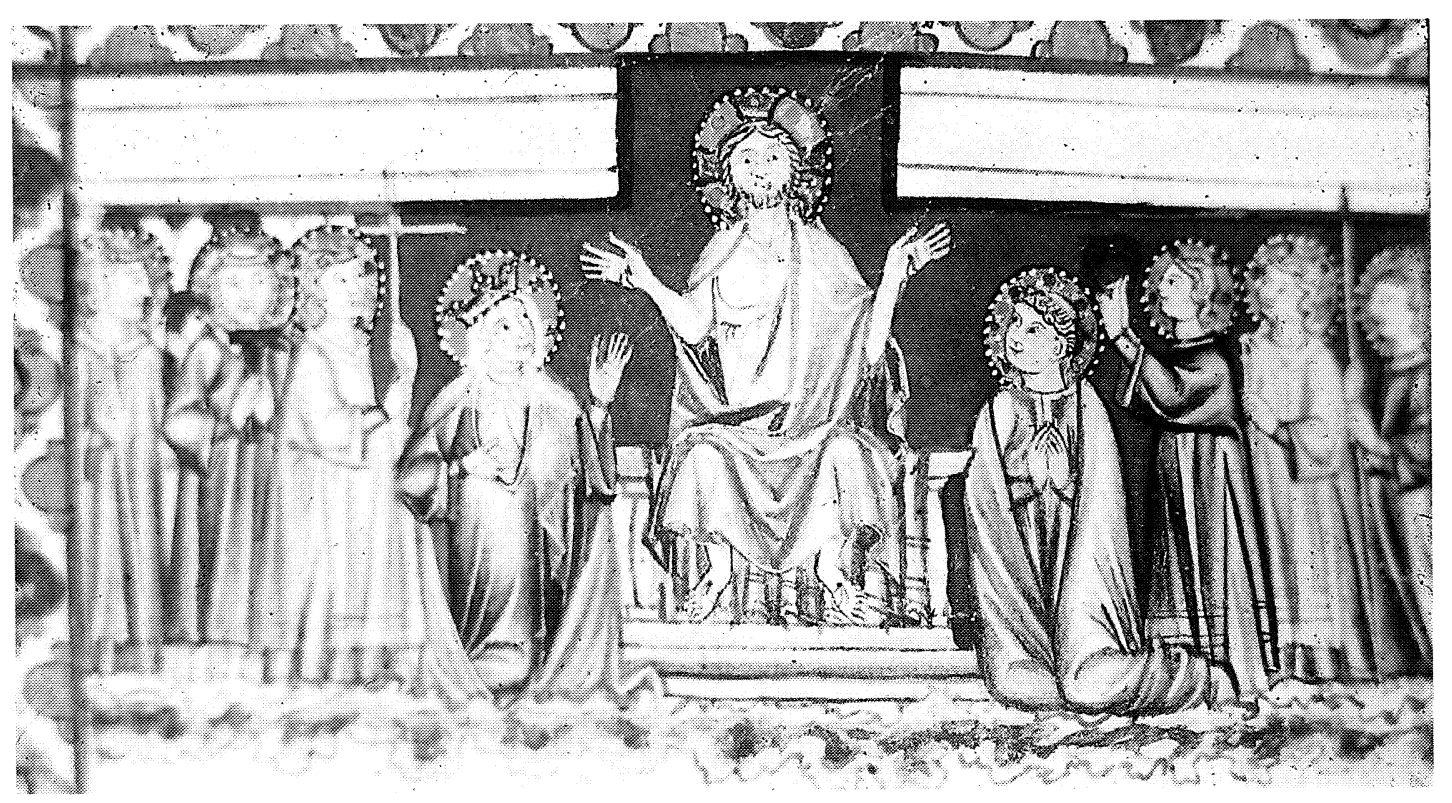

9

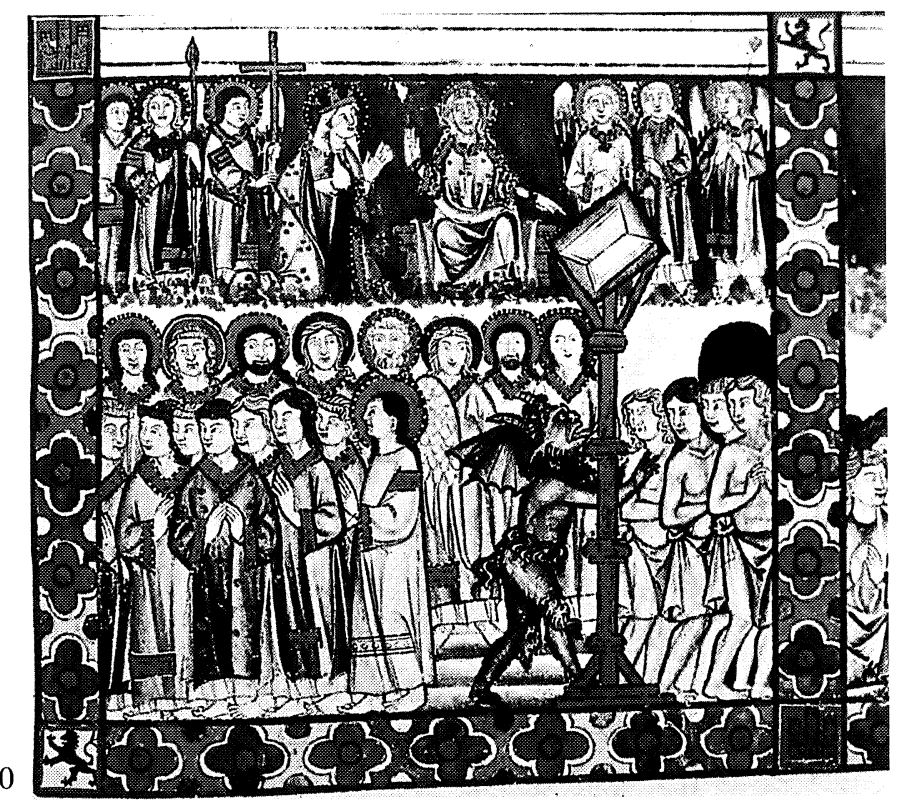

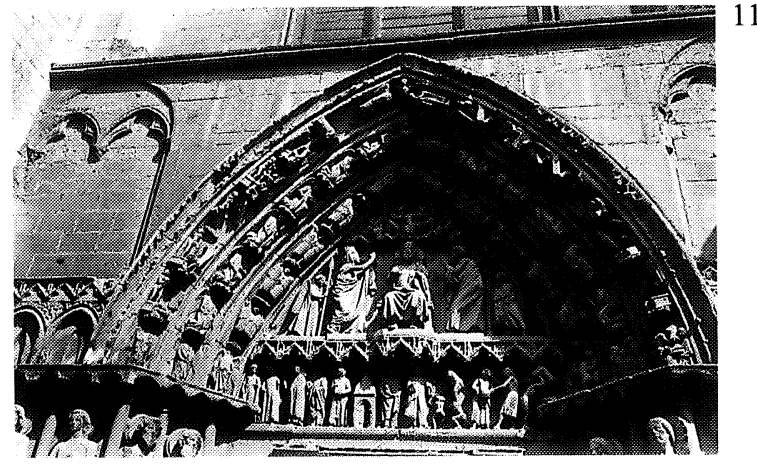

Fig. 9. Juicio final. Cantiga 50.

Fig. 10. Cantiga 80. Cantigas de santa María, códice rico, (ms. T.I.1.) El Escorial. Biblioteca del Monasterio.

Fig. 11.Juicio final. Puerta de la Coronería. Burgos, Catedral. 
critos del «Speculum Humane Salvationis», desde los que irradiará ampliamente, llegando a representarse hasta el siglo XVII, tanto en la miniatura como en la pintura monumental ${ }^{39}$.

En los manuscritos del «Speculum Humanae Salvationis» el capítulo XXXIX muestra la llamada doble intercensión. Aquí el Juez es el Padre a quien Cristo, para doblegar su cólera contra los hombres, le muestra las llagas que recibió por redimir a la Humanidad, mientras que paralelamente María enseña a Cristo el seno desnudo con que le alimentó de Niño.

$\mathrm{El}$ «Speculum...» se caracteriza por su carácter tipológico de tal manera que las escenas del Nuevo Testamento en él descritas se muestran en paralelo con otras imágenes que constituyen su prefiguración y que por lo general, aunque no siempre, son episodios del Antiguo Testamento. Así en este capítulo XXXIX es un raro episodio de la historia romana el escogido para prefigurar a Cristo: vemos frente a César a Antipater, uno de sus generales, mostrandole las heridas sufridas al servicio de Roma para disculparse ante él por una derrota ${ }^{40}$. Para prefigurar a María vemos a Esther ante Asuero suplicando por su pueblo.

En general podemos decir que en los ejemplos más completos del «Speculum Humanae Salvationis» figuran cuatro miniaturas que se refieren al Juicio Final: en dos de ellas Cristo y la Virgen, respectivamente, muestran al Padre el uno la llaga del costado y la otra a Cristo el seno con que le alimentó de Niño (Fig. 8); en una tercera miniatura aparece Antípater ante el César; en la cuarta Esther ante el rey Asuero. El texto que acompaña las imágenes de Cristo y la Virgen es muy expresivo: «Maria est nostra mediatrix... est nostra defensatrix... Christo ostendit Patri suo pro nobis sua vulnera, et Maria ostendit Filio suo pecto et ubera...» ${ }^{41}$.

El origen remoto de este tipo de intercesión de María se encuentra en Homero: en la Ilíada Hécuba, para convencer a su hijo Héctor de que no vaya a combatir con Aquiles, le enseña el seno con que lo alimentó de niño, mientras su padre, el viejo Príamo, se arranca cabellos y vestidos ${ }^{42}$.

Si bien parece que ya en el siglo VIII el patriarca de Alejandría German I se había referido a esta escena, es en el siglo XII y en el ámbito cisterciense en donde podemos asistir a su creación. La base está en la teoría de San Bernardo sobre la intercensión de la Virgen en su famoso sermón sobre la Natividad de María llamado «De Aqueductu» (CLXXXIII, 137-448): la Virgen es el canal por el cual nos llegan las aguas de la gracia pues Dios quiere que obtengamos todo a través de María. El pecado de Adán y Eva rompió las relaciones directas del hombre y Dios pero aunque Cristo se hizo mediador entre ambos está todavía muy lejos de nosotros por su divinidad. Además Cristo está irritado con los hombres por el sufrimiento que le provocaron. Por ello entre Cristo y la Humanidad pecadora existe una intermediaria, María. Ella intercede ante el Hijo y el Hijo ante el Padre. El Hijo escucha a su Madre y el Padre a su Hijo. Es la «scala salutis» ${ }^{43}$. San Bernardo dijo también: «Si la Majestad divina os asusta acudid a María... Ella es la escala de los pecadores» ${ }^{44}$.

Pero parece que el origen concreto del tema de la «scala salutis» está en el «De laudibus Beatae Mariae Virginis» de Ernaldo de Chartres, abad de Bonneval en 1138 y muerto en 1156, que

\footnotetext{
${ }^{39}$ Sobre el «Speculum humanae Salvationis» véanse los trabajos monográficos citados anteriormente. Conviene recordar también a E. Mâle, L'art réligieux de la fin du Moyen Age.., op.cit., supra., pp. 229-246, que difundió en círculos más amplios la importancia de los manuscritos iluminados y las ediciones impresas con grabados del «Speculum...» por su influencia sobre los artistas. Sobre la escena de la Virgen mostrando sus senos desnudos a Cristo Vid. P. Perdrizet, La Vierge de Misericorde. Étude d'un thème iconographique, París, 1908, pp. 237-252.

${ }^{40}$ Perdrizet, La Vierge....

41 Ibidem.

42 Ibidem.

${ }^{43}$ Ibidem.

${ }^{44}$ L. Réau, Tom. I,vol. 2, pp. 131-134. En S. Bernardo, Obras completas, ...vol. IV, pp. 425-27 se lee: «Pero quizá te sobrecoge su majestad divina, porque aunque es hombre sigue siendo Dios. ¿Quieres contar con un abogado ante él? Recurre a María... El Hijo atenderá a la Madre, y el Padre al Hijo. Hijos míos, ella es la escala de los pecadores...».
} 
era muy amigo de S.Bernardo. Un pasaje, atribuído a él por S.Alfonso de Ligorio y por otros autores posteriores, hace alusión directa al tema diciendo: «Securum accesum jam habet homo ad Deum, ubi mediatorem causae suae Filium habet ante Patrem, et ante Filium matrem. Christo, nudato latere, Patris ostendit latus et vulnera, Maria Christo pecto et ubera. Nec potest ullo modo esse repulsa ubi concurrant et orant omni lingua disertius haec clementiae monumenta et caritatis insignia...» ${ }^{45}$.

Los dos ejemplos de las Cantigas son los únicos por mi conocidos en el siglo XIII ${ }^{46}$ pero a partir del XIV y en el siglo XV el tema se difundirá bastante llegándose a apreciar entonces diversas variantes. Hay que señalar, sin embargo, que en las Cantigas es solamente María la que intercede ante su propio Hijo que es el Juez. Mientras que por lo general en las versiones posteriores suele ser una doble intercensión, la de María y la de Cristo, mostrando la una su pecho desnudo y el otro sus llagas, ante el Juez identificado con el Padre eterno.

En el «Speculum Humane Salvationis» de origen boloñés de comienzos del siglo XIV, conservado en la catedral de Toledo, dos miniaturas diferentes, pero consecutivas, muestran esta doble intercensión. En la primera Cristo en pie muestra al Padre (envuelto todavía en una arcaizante mandorla) las llagas de manos, pies y costado. En la segunda María, también en pie, muestra a un Dios Padre similar al anterior sus dos senos desnudos ${ }^{47}$. En otras versiones del «Speculum Humanae Salvationis» por mi conocidas aparecen siempre los mismos tres personajes: la Virgen muestra su pecho desnudo al Padre; Cristo señala sus llagas al Juez; el Juez es el Padre.

Pese a su pervivencia hasta el siglo XVII esta iconografía responde al tipo de «imago pietatis», propia del tardogótico y constituye la yuxtaposición de dos imágenes que, en ocasiones, pueden aparecer separadas, el Varón de Dolores y la «Virgo mediatrix».

En el siglo XV esta «scala salutis» aparece con relativa frecuencia en los Libros de Horas. En el ms. Res. 191 (f. 145v.) de la Biblioteca Nacional de Madrid la Virgen se arrodilla al pie de la cruz y muestra su pecho desnudo al Hijo (Fig. 12). Cristo, crucificado, lleva una de sus manos desclavada a la llaga del costado mientras que el Padre eterno, en lo alto del cielo contempla a ambos. Esta imagen acompaña a la oración «O intemerata» que es muy frecuente en este tipo de libros y que no hace ninguna alusión concreta a estos episodios ${ }^{48}$.

En el llamado Libro de Horas Moralizante o de Carlos V (Madrid, Biblioteca Nacional, Vit, 24-3, p. 130) en el margen izquierdo de la página vemos a la Virgen arrodillada y a Cristo en pie a su lado mostrando respectivamente sus senos y llagas mientras que Dios Padre figura en lo alto dentro de una nube ${ }^{49}$ (Fig. 13).

45 Texto tomado de PERDRIZET, «La Vierge...». La traducción dada por Trens dice así: «Oh hombre, tienes asegurado el acceso a Dios, puesto que la Madre está ante el Hijo, el Hijo ante el Padre. La Madre muestra a su Hijo su seno y pechos; el Hijo presenta al Padre el costado abierto y las llagas. Allí no cabe repulsa alguna, en donde la caridad se manifiesta de manera tan generosa». Numerosos dichos y versos populares se refieren a este tema, como el que dice:»Por aquel pecho que te dió, siendo tu Niño, protección y alimento a tu pueblo da». O aquel otro: «Si antaño con tus pechos sus lágrimas calmabas, lo aplacas ahora, enojado por nuestros excesos». Vid. M. Trens, María. Iconografía de la Virgen en el arte español, Madrid, 1946, p. 371. El mismo autor señala un texto anónimo español, probablemente del siglo XVI, en el que la Virgen defiende a los pecadores con las palabras siguientes: «Por la leche que mamaste, / Hijo, de mi casto pecho, / por el vientre en que encarnaste, / por la Pasión que pasaste / por nuestro bien y provecho.» (Idem, p. 372).

46 Tampoco encuentro ninguno tan temprano en G. Schiller, vol. 2, pp. 224-226.

47 Vid. E. Silber, «The reconstructed Toledo Speculum Humanae Salvationis: the Italian Connectio in the early Fourteenth Century» en Journal of the Warburg and Courtould Institute, 43 (1981) 33-51. Según la autora este manuscrito ya no se encuentra en Toledo aunque ha podido hacer la reconstrucción gracias a las fotos conservadas en el Archivo Mas de Barcelona.

48 A. Domíguez Rodríguez, Libros de Horas del siglo XV en la Biblioteca Nacional, Madrid, 1979, p. 40; EADEM, Iconografía de los Libros de Horas del siglo XV de la Biblioteca Nacional, Madrid, 1993, p. 871. En pp. 1160-61 recojo el texto de la oración «O intemerata».

49 Vid. A. Domíguez Rodríguez, Libros de Horas del siglo XV..., p. 95; EADEM, Iconografía de los Libros de Horas del siglo XV..., p. 871 . 
Y en las famosas Horas de Catherine de Clèves, de hacia 1435, aparece en una miniatura María arrodillada mostrando su seno al Hijo en el Juicio Final (Fig. 14), estando Dios Padre en lo alto, mientras que en otra vemos una Crucifixión en la que Cristo con una de sus manos desclavada muestra sus llagas al Padre mientras que María, arrodillada al pie de la Cruz, enseña su pecho desnudo al Hijo ${ }^{50}$ (Fig. 15).

El mismo tema aparece también en las Horas de Turín de Juan Van Eyck ${ }^{51}$ y en el miniaturista Simón Bening ${ }^{52}$. Lo vemos en libros grabados como las Grandes Horas de Antoine Verard ${ }^{53} \mathrm{o}$ en unas vidrieras inspiradas en el «Ars moriendi» ${ }^{54}$. También en pinturas de Filippino Lippi, Konrad Witz y Holbein el Viejo ${ }^{55}$.

Después del concilio de Trento el tema se mantiene pues Molanus, el teólogo de Lovaina muerto en 1585 que defendió contra las críticas de los reformistas la iconografía católica, lo recomendó ${ }^{56}$. Tenemos todavía importantes versiones de Rubens ${ }^{57}$ y Mateo Cerezo ${ }^{58}$ en el siglo XVII, momento en que se la denomina doble intercensión o «scala salutis», pero desaparece, al parecer, en el siglo XVIII ${ }^{59}$.

Como resumen final podemos indicar que existen básicamente dos variantes de la «scala salutis» o doble intercensión. En la primera, que es la más común, aparece dentro del Juicio Final. La segunda variante se presenta en relación con la Crucifixión, haciéndose alusión en ambas a la función de María como corredentera, aunque la segunda escena evoca más directamente la pasión de la Virgen, paralela a la de Cristo o «compassio».

En las dos miniaturas de las Cantigas 50 y 80 nos encontramos con una fase inicial dentro de este tipo de Juicio Final, con dos únicos personajes, en donde la Virgen muestra a su Hijo Juez

50 Sobre la iconografía mariana del Libro de Horas de Catherine de Clèves Vid:»)An Inmaculist Cycle in the Hours of Catherine of Cleves», en Oud Holland, 87 (1973) 177-204. (Agradezco a M. C. Lacarra Ducay el envío de este artículo). El Libro de Horas citado se fragmentó en el pasado en dos sectores, uno de ellos en la antigua colección Guennol que se ha juntado nuevamente con el de la Biblioteca Morgan de Nueva York (ms. M. 945). Las miniaturas por mi citadas ocupan la p. 28 con el Juicio Final y p.160 con la Crucifixión del antiguo sector Morgan. Sobre este códice Vid. The Hours of Catherine of Cleves, Introduction and Commentaries by John Plummer, New York, 1975.

51 Vid. A. Chatelet, Jean Van Eyck enlumineur, Strasbourg, 1993, fig. 18. En este Libro de Horas la miniatura acompañaba a una oración que se decía en la Misa, tras la Comunión, y que solicitaba la intercensión de María. Ibidem, p. 134.

Citado también por Elisa Bermejo, «Intercesión de Cristo y la Virgen ante el Padre Eterno de Simón Bening en San Isidoro de León» en Estudios de Arte. Homenaje al profesor Martín González, Valladolid, 1995, pp. 491-493.

52 Vid. E. Bermejo, ibidem, pp. 491-493.

${ }_{53}$ Perdrizet, p. 244

${ }^{54}$ Ibidem, p. 241

${ }^{55}$ G. Schiller, Vol. II, pp. 224-225. Otros ejemplos en D. Koepplin, «Interzession», col. 346-352 en E. Kirschbaum y otros, Lexikon der Christlichen Ikonographie, Basel-Wien, 1970. En un cuadro de Holbein el Viejo del año 1506 unas inscripciones ponen el siguiente diálogo en boca de sus personajes: «Padre, mira mis heridas rojas, ayuda a los hombres a salir de toda zozobra por mi amarga muerte. Señor envaina tu espada que has sacado de su funda y mira al seno que ha alimentado a tu Hijo. Y el Padre contesta: Usaré la misericordia con todos aquellos que morirán con arrepentimiento».

56 «De historia sacrarum imaginum», II, 31: «Imago Deiparae ostendentis Filio suo ubera desumpta est verbis S.Bernardi, quae ex sermonibus ejus frequenter citari solet: $O$ Homo, securum habes accessum ad Deum, ubi Mater ante Filium, Filus ante Patrem. Mater ostendit Filio pectus et ubera, Filius ostendit Patri latus et vulnera: ibi non potest esse ulla repulsa, ubi tot sunt caritatis insignia. Verum, sicut figurate intelligo verba Bernardi, sic imaginem ex eis verbis desumptam intelligendam arbitror» (he subrayado las palabras que Molanus pone en boca de S.Bernardo). La cita procede de Perdrizet, La Vierge de Misericorde..., p. 250.

57 Ibidem, pp. 238-239. RÉAU, op. cit., p. 132, localiza el cuadro de Rubens: Cristo renunciando a fulminar el mundo que fue pintado para los recoletos de Gante y se conserva en el Museo de Bruselas.

${ }_{58}$ M. Trens, p. 375 y fig. 229.

${ }^{59}$ Sobre la doble intervención o «scala salutis véanse también L. Réau, Icconographie de l'art chrétien, vol. II, 2, pp. 122-123 y M. Meiss, «»An early Altarpiece from the Cathedral of Florence» en Bulletin of the Metropolitan Museum, Juin, 1954. 


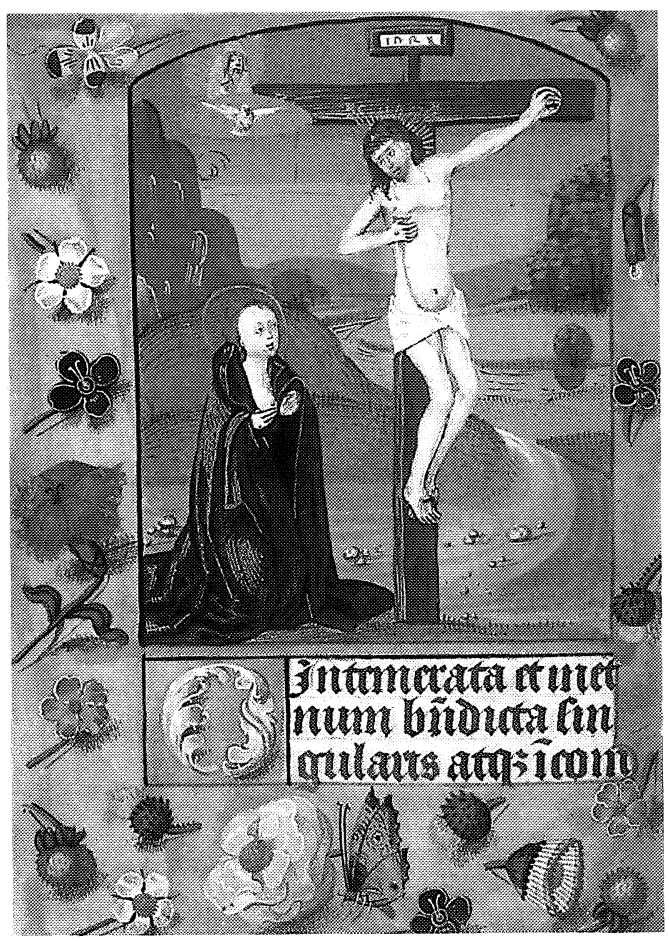

12

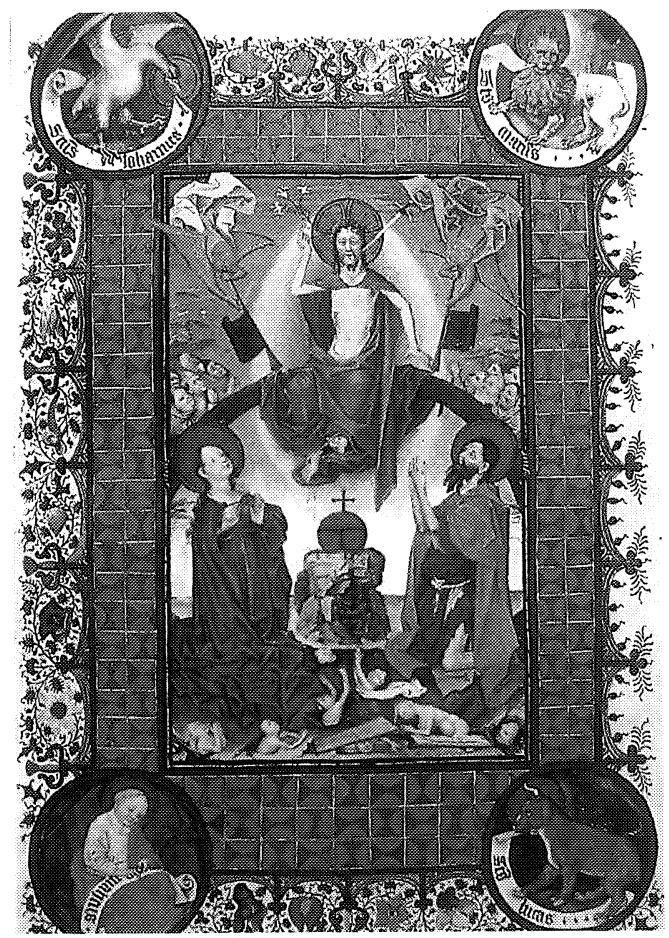

13

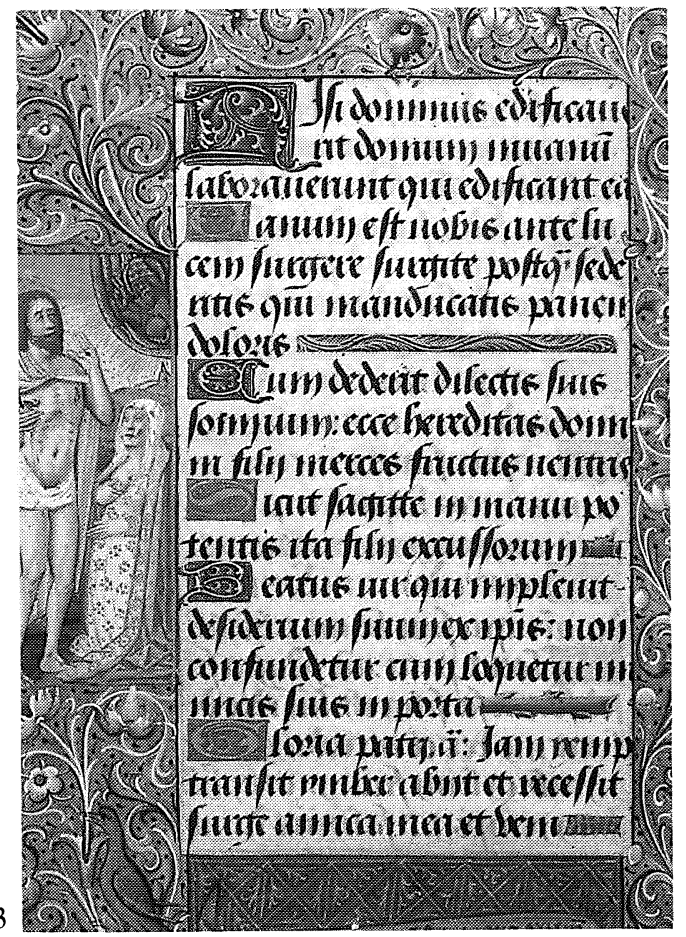

14

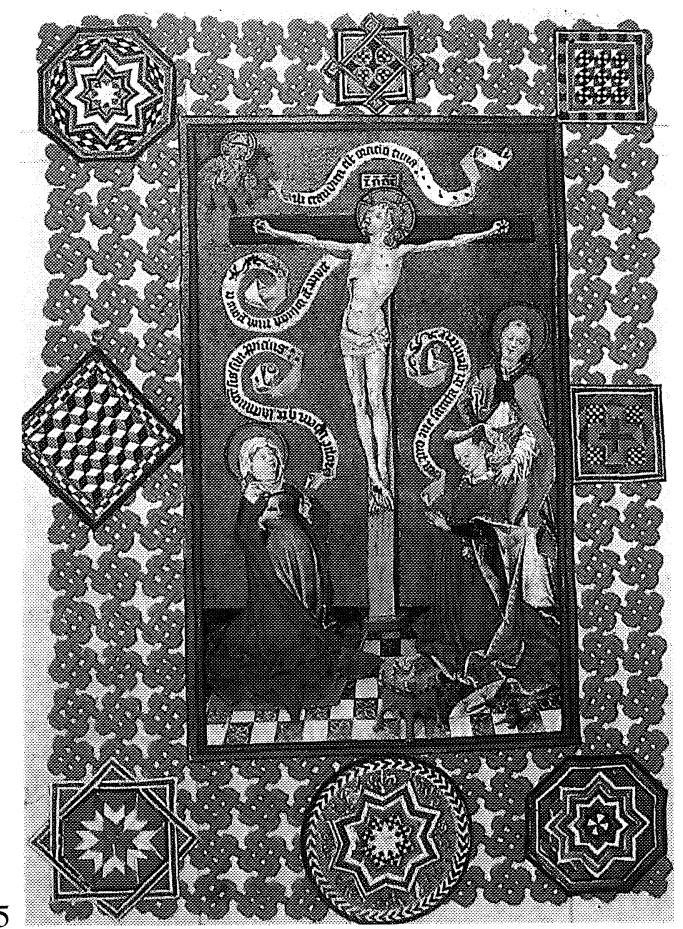

Fig. 12. La Virgen mostrando el pecho a su Hijo. Libro de Horas (ms. Res, 191, f. 145v.) Madrid, Biblioteca Nacional.

Fig. 13. La Virgen mostrando el pecho a su Hijo. Libro de Horas de Carlos V, (ms. Vit. 24-3, p. 130) Madrid, Biblioteca Nacional.

Fig. 14. Juicio final.

Fig. 15. Crucifixion. Libro de Horas de Catherine de Clèves, págs. 28 y 160. Nueva York, Biblioteca Morgan. 
el pecho desnudo. El carácter primario del Juicio Final de las Cantigas, en donde el diálogo mudo sobre la redención transcurre únicamente entre Cristo y la Virgen, sin que se represente la figura de Dios Padre, nos habla de una etapa incipiente de esta imagen, que puede haber derivado directamente del ámbito cisterciense, aunque no sepamos, por el momento, las vías ni los intermediarios.

Conviene destacar que en otras Cantigas (360, 403 y 422), que se suelen considerar posteriores en cronología, por lo que, quizá, no se llegaron a copiar en el «códice rico» que ha llegado a nosotros inacabado, aunque si en otros manuscritos de la obra alfonsí, existen versos que se refieren con todo detalle al dolor de María al pie de la cruz (o «compassio») y también a la escena en que la Virgen muestra sus pechos al Hijo intentando calmar su ira. Pero de estas cantigas nunca se hicieron ilustraciones historiadas al modo que estudiamos. Habrá que deducir de estos datos que en el caso de las Cantigas de Santa María las nuevas imágenes se iniciaron en las pinturas y sólo posteriormente pasaron al texto ${ }^{60}$.

\section{Un nuevo concepto de la salvación humana}

Las miniaturas de las Cantigas del códice «rico» que hemos analizado, nos muestran la presencia en el arte cristiano de un nuevo concepto de salvación que anticipa, y anuncia, el que se difundirá desde el siglo XIV en las versiones manuscritas, y más tarde también impresas, del «Speculum Humanae Salvationis».

El «Speculum Humanae Salvationis» es un gran poema latino que ha sido considerado como una de las obras más significativas de la baja Edad Media. Fue compuesto en torno al año 1324, posiblemente en la Germania meridional y consta de 45 capítulos, con 100 versos cada uno, que se extienden desde el pecado original hasta la Redención.

En la obra se acentúan los aspectos mariológicos : en la continua cadena de pecados cometidos por la estirpe humana, desde el Edén hasta el Juicio Final, la única interrupción se debe a María, santificada antes de su nacimiento y partícipe con su «compassio» de la Redención. El elemento tipológico es otra característica de la obra en la que cada episodio del Nuevo Testamento es el «antitypus», al que se refieren tres «tipi» o modelos alegóricos, tomados en su mayoría del Antiguo, o si no de literatura apócrifa. Al final de la misma se añaden diversos capítulos sobre los Dolores de Cristo y sobre los Gozos y Dolores de la Virgen.

La vida de la Virgen recibe casi más atención que la de Cristo y su papel como intercesora se enfatiza en los capítulos XXXVII a XXXIX ${ }^{61}$.

Se ha conservado un número elevadísimo de manuscritos e impresos del «Speculum...» de los siglos XIV y XV (unos 380) que son testimonio del éxito que alcanzó. Casi un tercio de ellos se ilustraron con unas 192 escenas. Tuvo gran influencia con su iconografía en el arte bajomedieval pero desde la Edad Moderna las nuevas corrientes racionalistas descartaron este tipo de obras alegóricas.

Si durante mucho tiempo se atribuyó a la obra un origen dominico hoy se la ha llegado a considerar creación franciscana ${ }^{62}$. A principios del siglo XIV el emperador Luis el Bávaro

${ }^{60}$ J. W. Marchand y S.Baldwin, «Singers of the Virgin in Thirteenth-century Spain» en Bulletin of Hispanic Studies, LXXI (1994) 169-184. Agradezco a Martha Schaffer que me informara sobre este importante artículo. Estos autores citan los textos de Cantigas no por un manuscrito concreto sino por la edición de W. Mettmann, Cantigas de Santa María, vol. III, Madrid, 1989, pp. 231, 307 y 349. La cantiga 422 de la ed.de Mettmann se refiere a «como Santa Maria rogue por nos a seu fillo eno dia do juycio» y uno de sus versos dice lo siguiente: «U verás dos santos as compannas espantadas,/ mostra-ll'as tas tetas santas que ouv'el mamadas...».

${ }^{61}$ Michael Thomas «Lo Speculum Humanae Salvationis e l'idea occidentale della redenzione» en Nova Rivista Storica, LVI (1974) pp. 379-395.

62 Thomas, pp. 381-382. 
(1328-1347), en conflicto con el papa Juan XXII (1316-1344), residente éste último en Aviñón, estaba íntimamente relacionado con el sector de los franciscanos espirituales, oponiéndose ambos al Papa. En este ambiente de notable influjo franciscano, hay que señalar la presencia, incluso, de Ubertino de Casale en la corte imperial de Baviera. Aquí debió surgir el «Speculum Humanae Salvationis» que llevaba en sí signos de modernidad religiosa, como la emancipación de los laicos frente al clero, un concepto de salvación ligado al individuo, a su voluntad y a sus valores morales ${ }^{63}$

La presencia de estas imágenes en que la Virgen aparece como corredentora, compartiendo la Pasión de su Hijo e interviniendo para salvar a los hombres en el Juicio Final apuntan a una nueva concepción del cristianismo, una nueva religiosidad que, según mi opinión, podía adquirir, a los ojos de algunos sectores del clero, una apariencia heterodoxa.

Un documento del año 1279, llamado «memoriale secretum» y conservado en el Vaticano, recoge el informe realizado por el legado papal, obispo Pietro de Rieti, que fue enviado a Castilla por el Papa Nicolás III para investigar una serie de quejas hechas contra Alfonso por dos exiliados, el arzobispo Gonzalo García de Compostela y el obispo Martín Fernandez de León. Entre las quejas, que expresan enorme agresividad contra el rey Sabio, la mayoría se refieren a los «gravamina» o cargas económicas impuestas por el rey. Hay también críticas al intervencionismo regio en las elecciones episcopales. Pero existe una acusación inesperada del que no se ha encontrado explicación concreta por el momento y es la acusación de un «novum ordinem seu religionem» establecido por el rey ${ }^{64}$.

Pienso que estas imágenes de las Cantigas hacen alusión a un entorno regio, influido quizá por los franciscanos espirituales, diferente a la ortodoxia romana y cuyas creencias pudieron ser consideradas como una nueva religión. Existen además esas obras astrológicas y sobre todo las oraciones al planeta Mercurio del Libro de Astromagia, compilado e iluminado para Alfonso X el Sabio, que aumentan las dudas sobre la ortodoxia del monarca ${ }^{65}$.

Hay que pensar que las crónicas diversas silenciaron la posible heterodoxia del rey Alfonso pues, como yo misma he estudiado ${ }^{66}$ los numerosos retratos del rey interviniendo como trovador, o más bien como sacerdote, ante la Virgen y Cristo, predicando como un intermediario entre la divinidad y los fieles, prescindiendo del clero, no pudieron ser aceptados por la Iglesia.

\footnotetext{
${ }^{63}$ Ibidem pp. 383 y ss.

${ }^{64}$ P. Linehan, «The Spanish Church revisited: the Episcopal Gravamina of 1279» en Authority and Power. Studies on Medieval Law and Governement presented to Walter Ullmann on his Seventieth Birthday, por B. Tierney y P. Linehan (eds.). Para esta sublevación contra el rey Sabio encabezada por su hijo Sancho, y las incógnitas que todavía presenta, véanse M. González Jiménez, Alfonso X (1252-1284), Palencia, 1993, pp. 95-155 y J. F. O. Callaghan, El rey Sabio. El reinado de Alfonso X de Castilla, Sevilla, 1996, pp. 301-332.

${ }^{65}$ Vid. A. Domínguez Rodríguez, «Poder, ciencia y religiosidad en la miniatura de Alfonso X el Sabio», op.cit.supra; EADEM, «El Libro de los juegos y la miniatura alfonsí», op.cit.supra. Aporto un nuevo dato sobre Alfonso como Anticristo que me ha proporcionado, ante mi pregunta sobre si tenía noticias sobre la posible heterodoxia del rey Sabio, Emilio Mitre, catedrático de Historia Medieval en la Universidad Complutense. «En 1258, cuando Salimbene encontró por última vez a Gerardo de Borgo, éste, que escrutaba siempre el porvenir de acuerdo con los métodos joaquinitas, identificó al personaje que debía realizar los misterios del fin de los tiempos. En este fecha es el rey de Castilla Alfonso X quien es designado como el Anticristo. En Lombardía eran los gibelinos los amigos de este príncipe. Es, ciertamente, una vocación de condenado pero no es menos cierto que se trata de una misión providencial que cumplir» en Jacques PAUL, «Le joachinisme et les joachinites au milieu du XIIIe siècle d'après le témoignage de Fra Salimbene» en 1274. Annèe Charnière. Mutations et continuités, Colloques internationaux del CNRS (Lyon, 1974), París, 1977, p. 804. Tomada esta referencia de Fra Salimbene, Chronica, en «Monumenta Germania Historica. Scriptores», tom. 32, p. 456. En un trabajo del propio E. Mitre («Hérésie et culture dirigeante dans la Castille de la fin du XIIIe siècle. Le modèle d'Alphonse le X», en Heresis, 9 (1987) 33-47, podemos ver que no existen referencias históricas a la existencia de herejías concretas en época del rey Sabio.

${ }^{66}$ A. Domínguez Rodríguez, «Imágenes de un rey trovador...», op.cit.supra.
} 
Alfonso X se presenta —en mi opinión - como un rey gibelino, a quien, si bien sólo se enfrenta con la Iglesia al final de su reinado, no parece adecuado atribuirle un grado tan elevado de patronazgo en las catedrales de su reino como Rafael Cómez Ramos, y otros tras él, han considerado ${ }^{67}$.

En una ocasión al menos, en la viñeta tercera de la miniatura de la Cantiga 50 que aquí estudiamos, el rey Alfonso aparece arrodillado y llorando ante el Cristo de la Flagelación, viviendo la Pasión de Cristo en una posición, similar por su paralelismo, a la de la Virgen abrazada a la cruz de la viñeta cuarta. Es posible que la predicación franciscana que aconsejaba a los fieles revivir emocionalmente la Pasión de Cristo y la Compassio Mariae fuera llevada a extremos heterodoxos por Alfonso El Sabio ${ }^{68}$ que, en esta miniatura osó compararse con la Virgen.

En cualquier caso la iconografía tan avanzada para su época de la Crucifixión y Juicio Final en las Cantigas, tan diferente a los que vemos en las catedrales de Burgos y León, me hacen dudar de que dichos edificios deban ser considerados en su totalidad, como algo representativo de un patronazgo alfonsí. El rey Sabio en su testamento se olvidó de las catedrales góticas y ordenó ser enterrado en las antiguas mezquitas de Murcia y Sevilla (entonces reconvertidas en iglesias dedicadas a Santa María). Tras una iconografía tan diferente, entre las Cantigas y las catedrales, subyace una concepción del cristianismo suficientemente distinta por lo que creo deben ser revisadas algunas de las llamadas «empresas artísticas» alfonsíes ${ }^{69}$.

${ }^{67}$ R. Cómez Ramos, Las empresas artísticas de Alfonso X el Sabio, Sevilla, 1979, pp. XI-XIV y 65-91; las tesis de Rafael Comez se han mantenido por M. A. Castillo Oreja, «Alfonso X y el arte de su tiempo» en Alfonso X, catálogo de la Exposición, Toledo 1984, pp. 73-87 y A. Franco Mata, «Alfonso X el Sabio y las catedrales de Burgos y León» en NorbaArte, 7 (1987) pp. 71-81. Estos autores no han valorado suficientemente, en mi opinión, el hecho documentado de que Alfonso X decidiera en su testamento ser enterrado en las antiguas mezquitas mayores de Murcia (sus entrañas) y Sevilla (su cuerpo), olvidando las catedrales góticas, supuestamente promovidas por él. Vid. sobre esto A. Domínguez Rodríguez, «El testamento de Alfonso X y la catedral de Toledo» en Reales Sitios, 82 (1984) pp. 73-75.

${ }^{68}$ En la misma viñeta cuarta de la miniatura que comentamos se representa, de un modo bastante excepcional en el Occidente cristiano la iconografía del momento en que Cristo es clavado en la cruz. No está la cruz tumbada en tierra, como será usual en el gótico, sino que Cristo es clavado estando el madero enhiesto y clavado en tierra. No creo que ello tenga un significado doctrinal pero si nos habla del sentido innovador y casi irrepetible de muchos aspectos de la miniatura alfonsí. A la originalidad iconográfica de esta miniatura en que Cristo es clavado en la cruz me he referido en diversas ocasiones en las obras arriba citadas.

${ }^{69}$ Cómez Ramos, op.cit.; Castillo Oreja, op.cit.; Franco Mata, op.cit. El camino para la revisión estará en la realización de estudios monográficos como los de M. Karge, La Catedral de Burgos y la arquitectura del siglo XIII en Francia y España, Valladolid, 1995. 